\title{
Impacts of grass removal on wetting and actual water repellency in a sandy soil
}

\author{
Klaas Oostindie ${ }^{1,2}$, Louis W. Dekker ${ }^{1,2 *}$, Jan G. Wesseling ${ }^{1,2}$, Violette Geissen ${ }^{2}$, \\ Coen J. Ritsema ${ }^{2}$
}

\footnotetext{
${ }^{1}$ Wageningen University and Research, Alterra, Soil Physics and Land Use Team, P.O. Box 47, 6700 AA, Wageningen, the Netherlands.

${ }^{2}$ Wageningen University and Research, Soil Physics and Land Management Group, P.O. Box 47, 6700 AA, Wageningen, the Netherlands.

* Corresponding author. E-mail: louis.dekker@wur.nl
}

\begin{abstract}
Soil water content and actual water repellency were assessed for soil profiles at two sites in a bare and grasscovered plot of a sand pasture, to investigate the impact of the grass removal on both properties. The soil of the plots was sampled six times in vertical transects to a depth of $33 \mathrm{~cm}$ between 23 May and 7 October 2002. On each sampling date the soil water contents were measured and the persistence of actual water repellency was determined of field-moist samples. Considerably higher soil water contents were found in the bare versus the grass-covered plots. These alterations are caused by differences between evaporation and transpiration rates across the plots. Noteworthy are the often excessive differences in soil water content at depths of 10 to $30 \mathrm{~cm}$ between the bare and grass-covered plots. These differences are a consequence of water uptake by the roots in the grass-covered plots. The water storage in the upper $19 \mathrm{~cm}$ of the bare soil was at least two times greater than in the grass-covered soil during dry periods. A major part of the soil profile in the grass-covered plots exhibited extreme water repellency to a depth of $19 \mathrm{~cm}$ on all sampling dates, while the soil profile of the bare plots was completely wettable on eight of the twelve sampling dates. Significant differences in persistence of actual water repellency were found between the grass-covered and bare plots.
\end{abstract}

Keywords: Actual soil water repellency; Critical soil water content; Irregular wetting; Preferential flow; Transition zone; Water drop penetration time (WDPT) test.

\section{INTRODUCTION}

Recently it has become clear that soil water repellency is much more widespread than formerly thought. Its occurrence has been described on all continents, in climates ranging from seasonal tropical to subarctic, for multiple land uses including ploughed cropland, grasslands, shrub land, and a wide range of forest types, and in soils ranging from coarse- to fine-textured (e.g. Dekker and Jungerius, 1990; Dekker et al., 1999; Jaramillo et al., 2000; Lichner et al., 2010). However, the phenomenon is most prominent in course textured soils and is common in sandy soils supporting for instance turf or pasture grasses (e.g. Dekker et al., 2005; Lichner et al., 2011; Oostindie et al., 2008, 2011; Wallis et al., 1989).

Depending on its persistence, water repellency can reduce the affinity of soils for water such that they resist wetting for seconds or, in extreme cases, even for months (Ritsema and Dekker, 1995; Wessolek et al., 2008). Water repellency is most pronounced after prolonged dry spells (Oostindie et al., 2013) and usually disappears after prolonged wet periods (e.g. Greiffenhagen et al., 2006; Täumer et al., 2005). Afterwards, it may re-appear during drier periods when the soil water content drops below a critical threshold (Dekker et al., 2001; Oostindie et al., 2013).

Soil water repellency is typically confined to the organically-enriched upper few centimetres or decimetres of the soil and is thought to be caused primarily by a coating of long-chained hydrophobic organic molecules on individual soil particles (e.g. Morley et al., 2005). These substances may be released from a variety of plant species, decaying organic matter, soil fauna, and microorganisms (e.g. Mao et al., 2014, 2015; MataixSolera et al., 2007). This coating does not necessarily cover the soil particles completely nor is it always very thick. A thin and/or partial covering of the soil particles can render them water repellent (Bisdom et al., 1993). However, mineral particles need not be individually coated with hydrophobic material; intermixing of mineral soil particles with particulate organic matter, like remnants of roots, leaves, and stems, may also induce severe water repellency (Bisdom et al., 1993; Morley et al., 2005).

Soil water repellency is dynamic, it changes temporally and spatially as soil water contents change due to precipitation, irrigation, evaporation, or transpiration. Spatial variations in repellency have been shown to cause or enhance the formation of unstable wetting fronts, fingered flow or preferential flow (e.g. Heijs et al., 1996; Lichner et al., 2011; Ritsema et al., 1997). Water repellency in soil and the associated preferential flow are like "barriers" and "leaks" in the soil plumbing system, respectively (Moore et al., 2010). Water repellency may intensely affect water and solute movement at the field-scale, a process which has often been underestimated (Aamlid et al., 2009; Bauters et al., 2000; Orfánus et al., 2016; Ritsema and Dekker, 1995; Wessolek et al., 2009). Water repellency and its spatial variability have been shown to cause decreased infiltration of irrigation water and precipitation, non-uniform wetting of soil profiles, increased runoff, and leaching due to preferential flow (Dekker et al., 2001; Lichner et al., 2011; Ritsema et al., 1997; Rodný et al., 2015; Wessolek et al., 2009).

In general, water repellency is most severe during summer and decreases or disappears during the winter months, as a consequence of changing soil moisture conditions. The critical soil water content introduced by Dekker and Ritsema (1994) appears not to be a sharp static threshold above which a soil is wettable and below which a soil is repellent, but rather a transitional range. This range of critical soil water contents for a certain depth had been introduced by Dekker et al. (2001) as the "transition zone". Soil layers can be either wettable or slightly to extremely water repellent within the transition zone, depend- 
ing on the sequence of weather conditions and wetting history. Besides it seems to us that also the spatial variation in composition of soil organic matter and in amount of hydrophobic compounds might explain this variation with wettable and even extremely water repellent samples within the transition zone.

Although the occurrence and persistence of water repellency in soils under different types of plant covers, and the relationship of water repellency to soil water content, are well documented, there are comparatively few studies on changes in water repellency and soil water content in space and time comparing plant-covered and bare soils.

The main objective of this study was to assess the effect of vegetation removal on soil wetting and wettability of the soil profile. The present paper describes the effects of removing the grass cover of two plots in a dune sand pasture in comparison with two adjacent untreated plots. The impact of removing the grass cover was evaluated on 1) the spatial and temporal variations in wetting and moisture contents and on 2) the spatial and temporal existence and persistence of actual water repellency of the soil profiles.

\section{MATERIALS AND METHODS Experimental field, sites and plots}

The experimental field was located in a non-calcareous dune sand pasture near Ouddorp, in the south-western part of the Netherlands (51 $\left.81^{\circ} 31^{\prime \prime} \mathrm{N}, 3^{\circ} 90^{\prime} 85^{\prime \prime} \mathrm{E}\right)$. The area experiences a humid-temperate climate (mean monthly temperatures vary between $1.7^{\circ} \mathrm{C}$ in January to $17.0^{\circ} \mathrm{C}$ in July) with rainfall occurring throughout the entire year (averaged annual precipitation is $765 \mathrm{~mm}$ ). During the growing season there is a small precipitation deficit, in autumn and winter a precipitation surplus occurs. The soil consisted of fine sand with less than $3 \%$ clay to a depth of more than $3 \mathrm{~m}$ and was classified as Typic Psammaquent (Soil Survey Staff, 2006). The site was a grass-covered pasture (main species Poa pratensis) and not tilled for at least several decades. An organic matter content of $12.5 \%$ on dry weight basis was present in the surface layer $(0-2.5 \mathrm{~cm})$. This decreased to $9.5 \%$ in the second layer $(2.5-5 \mathrm{~cm})$. At depths of $7-9.5 \mathrm{~cm}$ an organic matter content of $4.8 \%$ was measured and at depths of $9.5-12 \mathrm{~cm}$ it was $2.4 \%$. It further decreased to $1.5 \%$ at depths of $14-16.5 \mathrm{~cm}$ and $1.1 \%$ at depths of $16.5-19$ $\mathrm{cm}$. Below this depth the organic matter content was found to be around $0.5 \%$. The organic matter content was determined after oven-drying a portion of the soil samples $<2 \mathrm{~mm}$ at $105^{\circ} \mathrm{C}$ and thereafter at $550^{\circ} \mathrm{C}$, and by calculating the loss of organic matter as percentage of the soil dried at $105^{\circ} \mathrm{C}$.

The soil was known to be severely to extremely water repellent to a depth of approximately $50 \mathrm{~cm}$ during dry periods (Dekker et al., 2000). At each site of the experimental field two adjacent $(2 \mathrm{~m} \mathrm{x} 4 \mathrm{~m})$ plots were studied. From one of them the grass cover was burned away (Fig. 1). The grass cover was totally removed on 31 March, 2002, only leaving behind some ashes. If present, the new developed shoots were flamed on the dates of soil sampling.

\section{Soil sampling}

Soil samples were taken at eight depths in vertical transects from the bare and untreated plots. The bare and grass-covered plot of site 1 were sampled on 23 May, 19 June, 31 July, 26 August, and on 12 and 27 September, 2002. Both plots of site 2 were sampled on 30 May, 25 July, 23 August, 4 and 18 September, and 7 October. Samples were taken at depths of $0-2.5$, $2.5-5,7-9.5,9.5-12,14-16.5,16.5-19,21-26$, and $28-33 \mathrm{~cm}$,

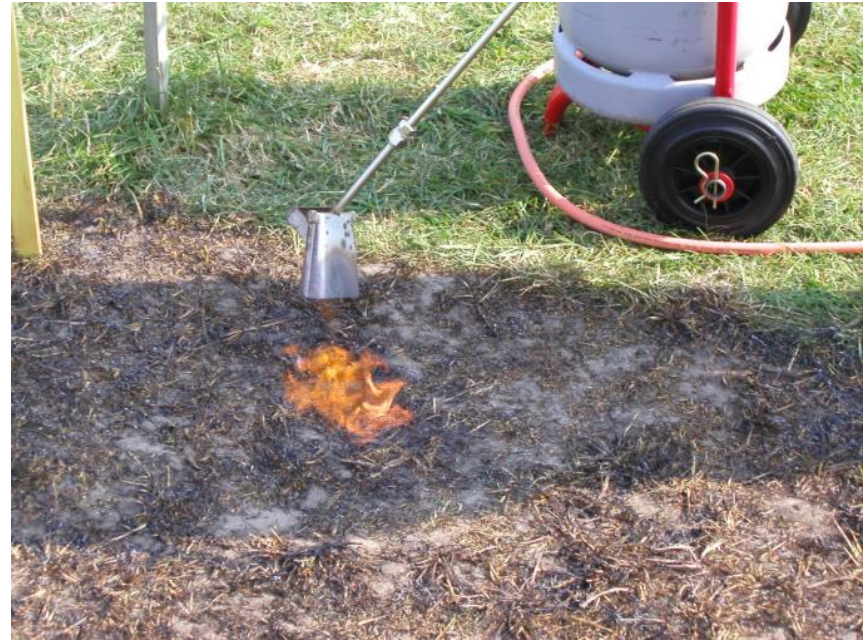

Fig. 1. Burning of the grass cover with a propane burner on 31 March, 2002.

using sharpened steel cylinders with a height of $2.5 \mathrm{~cm}$ and a diameter of $5 \mathrm{~cm}$. At each depth 15 adjacent samples were taken across a distance of approximately $75 \mathrm{~cm}$. The cylinders were pressed into the soil vertically, emptied into plastic bags and used again. The plastic bags were securely sealed to minimize evaporation from the soil. The field-moist soil in the plastic bags was weighed and the persistence of actual water repellency was measured. The terms 'actual' and 'potential' water repellency were introduced by Dekker and Ritsema (1994) to describe the level of repellency in soils at field moisture conditions, and in dried soil, respectively. All 2880 samples with a content of $50 \mathrm{~cm}^{3}$ had been oven-dried at $105^{\circ} \mathrm{C}$ for $24 \mathrm{~h}$ and weighed to obtain the volumetric soil water content.

\section{Water drop penetration time (WDPT) test}

The persistence or stability of actual water repellency of the field-moist soil samples was examined using the (WDPT) test. The time for the drop to enter the soil provides an indication of the stability or persistence of the repellency (Letey et al., 2000). During measurements, three drops $(\sim 0.05 \mathrm{ml})$ of distilled water from a standard medicine dropper were placed on the smoothed surface of a sample, and the time that elapses before the drops were absorbed was registered. Because the moisture tension of the soil depends on the temperature and air humidity (Doerr et al., 2002), we measured the persistence of water repellency of the soil samples in the laboratory under controlled conditions at a constant temperature of $20^{\circ} \mathrm{C}$ and a relative air humidity of $50 \%$. In general, a soil is considered to be water repellent if the WDPT exceeds $5 \mathrm{~s}$ (Dekker and Ritsema, 1994). We applied an index allowing a quantitative definition of the persistence of soil water repellency as described by Dekker and Jungerius (1990). In the present study seven classes of repellency were distinguished, based upon the time needed for the water drops to penetrate into the soil: class 0 , wettable, non-water repellent (infiltration within $5 \mathrm{~s}$ ); class 1 , slightly water repellent (5 to $60 \mathrm{~s}$ ); class 2, strongly water repellent (60 to $600 \mathrm{~s}$ ); class 3, severely water repellent (600 to $3600 \mathrm{~s}$ ); and classes 4, 5, and 6 extremely water repellent (more than $1 \mathrm{~h}$ ), with specific duration of 1 to $3 \mathrm{~h}$ (class 4), 3 to $6 \mathrm{~h}$ (class 5) and $>6 \mathrm{~h}$ (class 6). The WDPT measurements were performed on field-moist samples immediately after assessment of the wet weights of the samples. In this way the so-called "actual soil water repellency" is measured (Dekker and Ritsema, 1994; Dekker et al., 2009). 


\section{Precipitation and reference evapotranspiration}

To gain insight in the behaviour of the considered soil profile, we obtained daily values of reference evapotranspiration (ETref) and precipitation from a nearby weather station. The ETref was calculated using the Penman-Monteith equation. The amounts of precipitation, ETref and precipitation deficit and surplus for grass, before and between the sampling dates are given in Table 1.

\section{Statistical analysis}

For each date the effect of grass removal on the WDPT was tested using a regression model for ordinal response variables (MacCullagh and Nelder, 1989). This model was used because WDPT was measured in ordered categories and not on an interval scale. The regressions were carried out separately for the two sites, with treatment and depth as predictor variables, and the significance of treatment was tested with SPSS 17.0 statistic package.

\section{RESULTS \\ Soil water contents}

Soil water contents of the grass-covered plots were always expressively lower than found in the bare plots (Fig. 2). In general the mean water content decreased strongly in the soil profiles towards a depth of about $15 \mathrm{~cm}$. From that depth on, the grass covered plot showed a slight increase with depth, while the bare plots remained at the same level or showed a further decrease. The driest grass-covered soil profile, with mean water contents between 2 and 5 vol.\%, was sampled on 31 July. The precipitation and reference evapotranspiration in the period 20 June to 31 July amounted to a total of $85 \mathrm{~mm}$, and $135 \mathrm{~mm}$, respectively (Table 1), resulting in a precipitation deficit of $50 \mathrm{~mm}$. A precipitation surplus of $41 \mathrm{~mm}$ between 1 and 26 August resulted in obviously higher soil water contents throughout the soil profile of this grass-covered plot (Fig. 2).

One of the wettest bare soil profiles, with mean water contents between 8 and 30 vol.\%, was sampled on 27 September, as a result of $32 \mathrm{~mm}$ rain in the previous two weeks (Table 1).

\section{Site 1}

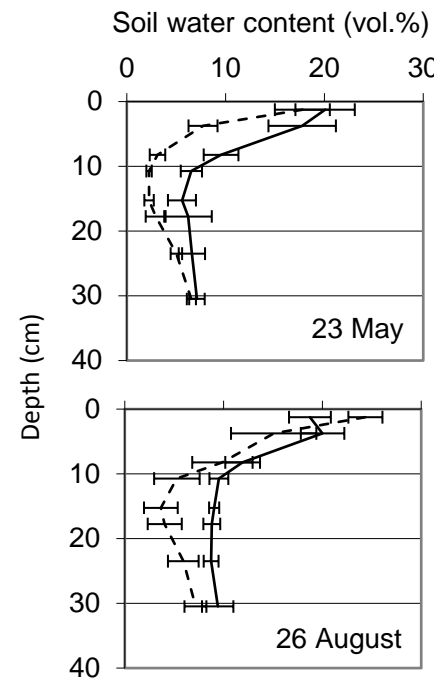

Soil water content (vol.\%)

Soil water content (vol.\%)
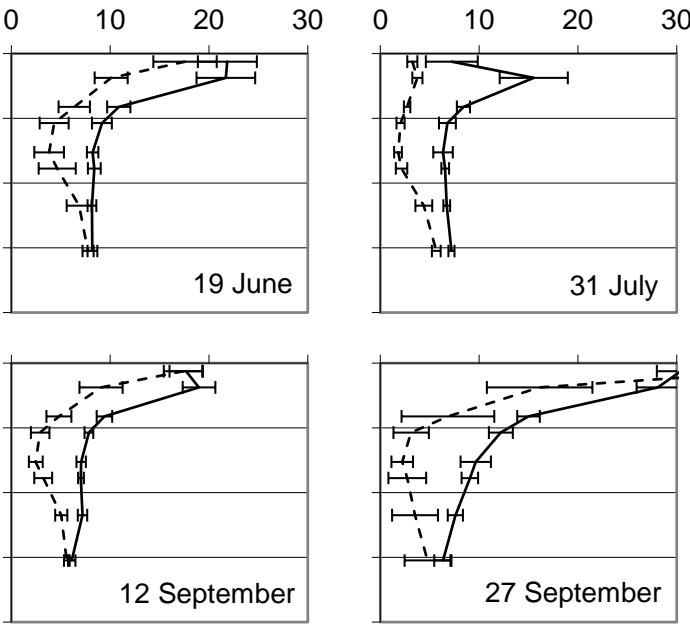

Site 2

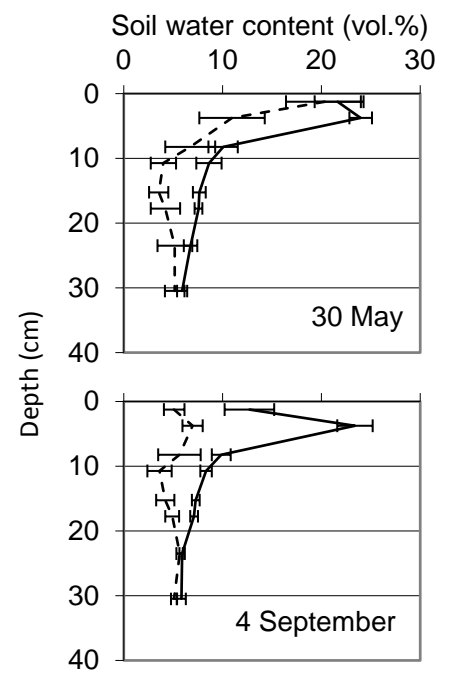

Soil water content (vol.\%)

Soil water content (vol.\%)
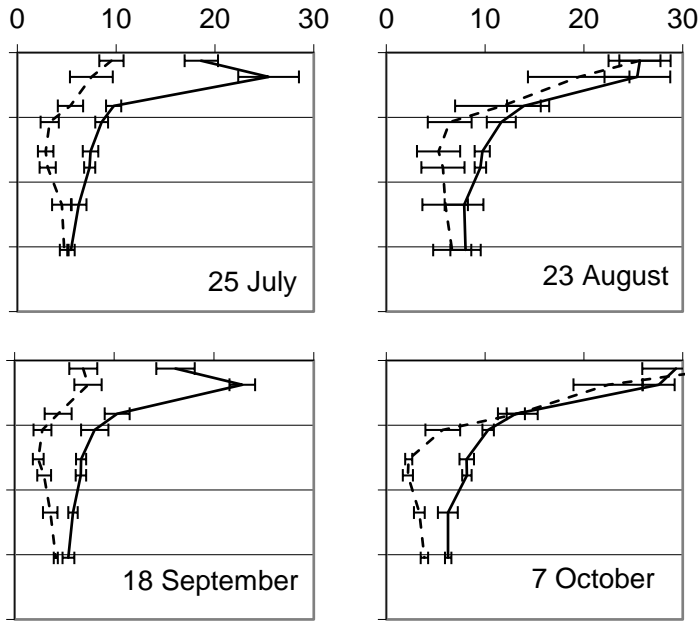

Grass-covered (unburned)

Bare (burned)

Fig. 2. Mean volumetric soil water contents at eight depths in the grass-covered plots (dashed lines) and bare plots (solid lines) of both sites on the sampling occasions. The standard deviations also have been indicated $(n=15)$. 
Table 1. Amounts of precipitation, reference evapotranspiration (ETref), and precipitation deficit and surplus for grass before and between the sampling dates of respectively, site 1 and site 2 in the Netherlands in 2002.

\begin{tabular}{lcccc}
\hline Period & $\begin{array}{c}\text { Precipitation } \\
(\mathrm{mm})\end{array}$ & $\begin{array}{c}\text { ETref } \\
(\mathrm{mm})\end{array}$ & \multicolumn{2}{c}{ Precipitation $(\mathrm{mm})$} \\
Deficit & Surplus \\
\hline 1-31 March & 44 & 43 & - & 1
\end{tabular}

Site 1

1 April-23 May

24 May-19 June

20 June-31 July

1-26 August

27 August-12 September

13-27 September

$\begin{array}{cc}62 & 125 \\ 74 & 82 \\ 85 & 135 \\ 112 & 71 \\ 8 & 38 \\ 32 & 22\end{array}$

125
82
135
71
38
22

63
8
50
-
30
-

-
-
-
41
-
10

Site 2

1April-30 May

31 May-25 July

26 July-23 August

24 August-4 September

5-18 September

19 September-7 October

\begin{tabular}{cccc}
68 & 146 & 78 & - \\
146 & 167 & 21 & - \\
108 & 89 & - & 19 \\
6 & 31 & 25 & - \\
13 & 26 & 13 & - \\
41 & 28 & - & 13 \\
\hline
\end{tabular}

Amazing are the excessive differences in soil water content at depths of 10 to $25 \mathrm{~cm}$ between the grass-covered plot and the bare plot on this date. One possible explanation for these differences is that in case of the grass-covered soil, water uptake took place by the roots which are predominantly found in the top 20 $\mathrm{cm}$. In case of bare soil, no uptake of water by vegetation took place, leading to affectedly high soil water contents.

Site 1 and 2 show similar results with substantially higher soil water contents in the bare versus the grass-covered plot (Fig. 2). The mean volumes of water in the upper $19 \mathrm{~cm}$ of the soil (total of 6 layers) in the grass-covered and bare plots of both sites have been expressed in $\mathrm{mm}$ water and are depicted for the twelve sampling dates in Fig. 3. In most cases the differences in amount of water between the bare and grass-covered plots were huge (10-15 mm) and on only few dates smaller (6$8 \mathrm{~mm}$ ). The water storage in the upper $19 \mathrm{~cm}$ of the bare soil was at least two times higher than in the grass-covered soil on 25 and 31 July, and 4 and 18 September.

Table 2 shows the temporal and spatial variability of the volumetric soil water contents at $2.5-5 \mathrm{~cm}$ depth in the grass-
Table 2. Mean, lowest and highest (range) of volumetric soil water contents at depths of $2.5-5 \mathrm{~cm}$ in the grass-covered and bare plots of both sites on the sampling occasions $(n=15)$ in the Netherlands in 2002 .

\begin{tabular}{lcccc}
\hline & \multicolumn{2}{c}{ Grass-covered } & \multicolumn{2}{c}{ Bare } \\
\hline $\begin{array}{l}\text { Sampling } \\
\text { date }\end{array}$ & $\begin{array}{c}\text { Mean } \\
(\mathrm{vol} \%)\end{array}$ & $\begin{array}{c}\text { Range } \\
(\mathrm{vol} \%)\end{array}$ & $\begin{array}{c}\text { Mean } \\
(\mathrm{vol} \%)\end{array}$ & $\begin{array}{c}\text { Range } \\
(\mathrm{vol} \%)\end{array}$ \\
\hline Site 1 & & & & \\
23 May & 7.7 & $5.6-11.9$ & 17.8 & $12.5-23.2$ \\
19 June & 10.1 & $7.0-12.8$ & 21.7 & $16.8-26.2$ \\
31 July & 3.8 & $2.9-4.6$ & 15.5 & $6.9-20.7$ \\
26 August & 15.1 & $7.5-21.8$ & 20 & $13.3-22.6$ \\
12 September & 9.1 & $6.5-14.7$ & 19 & $16.2-22.1$ \\
27 September & 16.1 & $8.2-25.9$ & 28.1 & $23.1-31.1$ \\
& & & & \\
Site 2 & & & & \\
30 May & 11 & $3.8-17.0$ & 24 & $22.5-26.1$ \\
25 July & 7.5 & $2.7-10.7$ & 25.4 & $16.9-29.1$ \\
23 August & 19 & $7.7-26.3$ & 25.4 & $17.1-29.4$ \\
4 September & 6.9 & $5.3-8.4$ & 23.4 & $20.6-26.6$ \\
18 September & 7.4 & $4.6-9.6$ & 22.8 & $20.2-24.8$ \\
7 October & 22.5 & $11.3-25.9$ & 27.6 & $24.7-30.6$ \\
\hline
\end{tabular}

covered and bare plots at both sites between 23 May and 7 October. The mean soil water content in the grass-covered plot of site 1 varied between 3.8 and 16.1 vol. $\%$ and of site 2 between 6.9 and 22.5 vol. $\%$. The mean water content in the bare plot of site 1 varied between 15.5 and $28.1 \mathrm{vol} . \%$, and in site 2 between 22.8 and 27.6 vol.\%.

The mean soil water contents at $2.5-5 \mathrm{~cm}$ depth in the bare plot of site 1 were on the sampling dates 4.9 to 12.0 vol.\% higher than those measured in the grass-covered plot. At site 2 these differences were even more pronounced; the soil water contents in the bare plot were 5.1 to 17.9 vol.\% higher.

The variability in soil water content at $2.5-5 \mathrm{~cm}$ depth at short horizontal distances was often high, as illustrated with the range of soil water contents in Table 2 . The smallest and greatest difference in soil water content over a distance of $75 \mathrm{~cm}$ in the grass-covered plot of site 1 was respectively 1.7 and 17.7 vol.\%, compared to 3.1 and 18.6 vol.\% at site 2 . The smallest and greatest difference in soil water content at $2.5-5 \mathrm{~cm}$ in the bare plot of site 1 were respectively 5.9 and $13.8 \mathrm{vol} . \%$, and in the bare plot of site 2 , respectively 3.6 and 12.3 vol.\%.
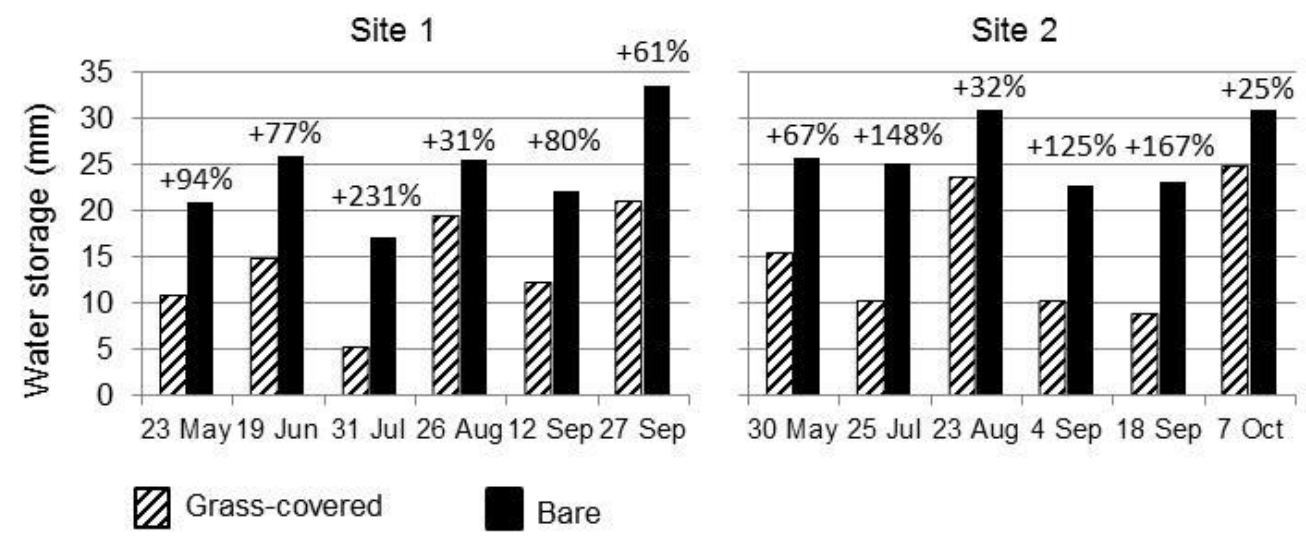

30 May 25 Jul 23 Aug 4 Sep 18 Sep 7 Oct

$\square$ Grass-covered $\square$ Bare

Fig. 3. Mean storage of $\mathrm{mm}$ water in the upper $19 \mathrm{~cm}$ of the soil $(n=15)$ in the grass-covered and bare plots of both sites on the respective sampling dates. The relative storage of water in the bare plots in comparison with the grass-covered plots is indicated above the bars. 


\section{Actual soil water repellency}

The development of actual water repellency in the soil profile of the grass-covered plot of site 1 (Fig. 4) was more pronounced than in the plot of site 2 (Fig. 5).

On 23 May slight to extreme water repellency was present to $19 \mathrm{~cm}$ depth in the soil profile of the grass-covered plot of site 1 (Fig. 4). In contrast, in the bare plot of this site, only 1 to 4 of the 15 samples taken in the layers down to $16.5 \mathrm{~cm}$ depth exhibited slight to severe water repellency, whereas all other samples were wettable. As a consequence of the high reference evapotranspiration of the grass-covered plot between 1 April and 23 May, which amounted to $125 \mathrm{~mm}$ in comparison with only $62 \mathrm{~mm}$ precipitation (Table 1), the amount of soil water storage in this plot was obviously less than in the bare plot (Fig. 3). The huge spatial difference in persistence at depths of $0-2.5 \mathrm{~cm}$ on 23 May is remarkable. Within a distance of $75 \mathrm{~cm}$ wettable as well as slightly, strongly, severely, and extremely water repellent soil samples were assessed. This may be due to irregular wetting of the surface layer by the $7 \mathrm{~mm}$ rain that fell in the previous four days.

All 120 samples in the bare plot of site 1 taken on 19 June were wettable, with WDPT less than $5 \mathrm{~s}$ (Fig. 4). The disappearance of soil water repellency was a consequence of the soil wetting by $74 \mathrm{~mm}$ rainfall since 23 May. Despite a slightly higher reference evapotranspiration $(82 \mathrm{~mm})$, the water storage in the grass-covered plot increased (Fig. 3) and the persistence of soil water repellency decreased (Fig. 4). It should be noted that, though the precipitation deficit was $8 \mathrm{~mm}$, the soil moisture content increased by almost $5 \mathrm{~mm}$. A possible cause of this contradiction is that the reference evapotranspiration is potential. In reality this value may be much lower due to a limited root water uptake (drought stress). The spatial variability in repellency of this plot was excessive at most depths. In particular, at 7-9.5 $\mathrm{cm}$ depth all 7 soil water repellency classes were represented.

The driest soil profile in the grass-covered plot at site 1 was sampled on 31 July. The precipitation deficit between 20 June and 31 July amounted $50 \mathrm{~mm}$ (Table 1, Fig. 6). This resulted in mean water contents of less than 5 vol.\% throughout the soil profile to $33 \mathrm{~cm}$ depth (Fig. 2). Severe to extreme water repellency did even occur at $0-2.5 \mathrm{~cm}$ depth on this date (Fig. 4).The water storage in the upper $19 \mathrm{~cm}$ of the bare plot was relatively low, but nevertheless amounted to $17 \mathrm{~mm}$ (Fig. 3). The mean soil water content at $0-2.5 \mathrm{~cm}$ depth dried to values below 10 vol.\% (Fig. 2), due to evaporation from this layer and the negligible amount of $1 \mathrm{~mm}$ precipitation in the eight days prior to the sampling. Owing to this, the surface layer in the bare plot became severely to extremely water repellent.

On 26 August soil water repellency was completely vanished for the layers between 0 and $5 \mathrm{~cm}$ and for the majority of the samples taken from the layers between 5 and $19 \mathrm{~cm}$

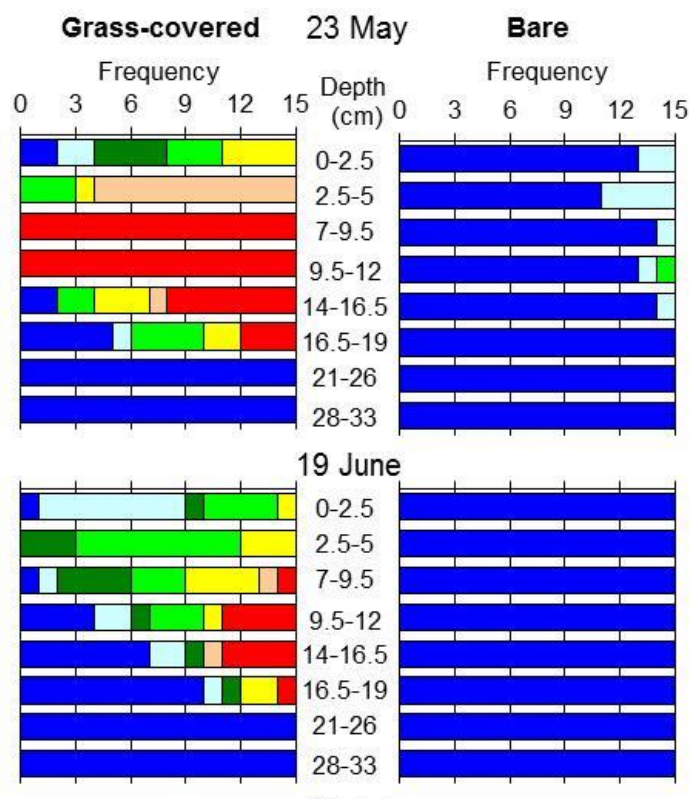

Site 1

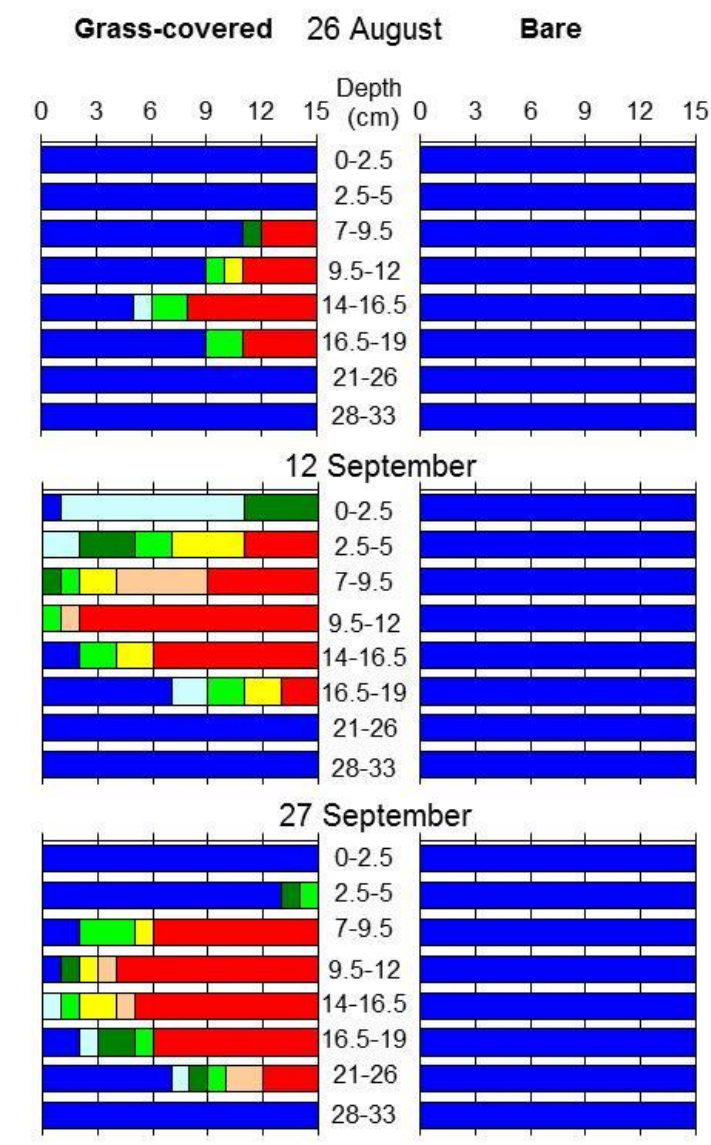

WDPT

$\square<5 \mathrm{~s} \quad \square 5-60 \mathrm{~s} \quad \square 60-600 \mathrm{~s} \quad \square 600-3600 \mathrm{~s} \quad \square 1-3 \mathrm{~h} \quad \square 3-6 \mathrm{~h} \quad \square>6 \mathrm{~h}$

Fig. 4. Frequency of the persistence of actual water repellency (WDPT class) of field-moist soil samples taken at eight depths in the grasscovered and bare plot of site 1 between 23 May and 27 September $(n=15)$. 
Site 2

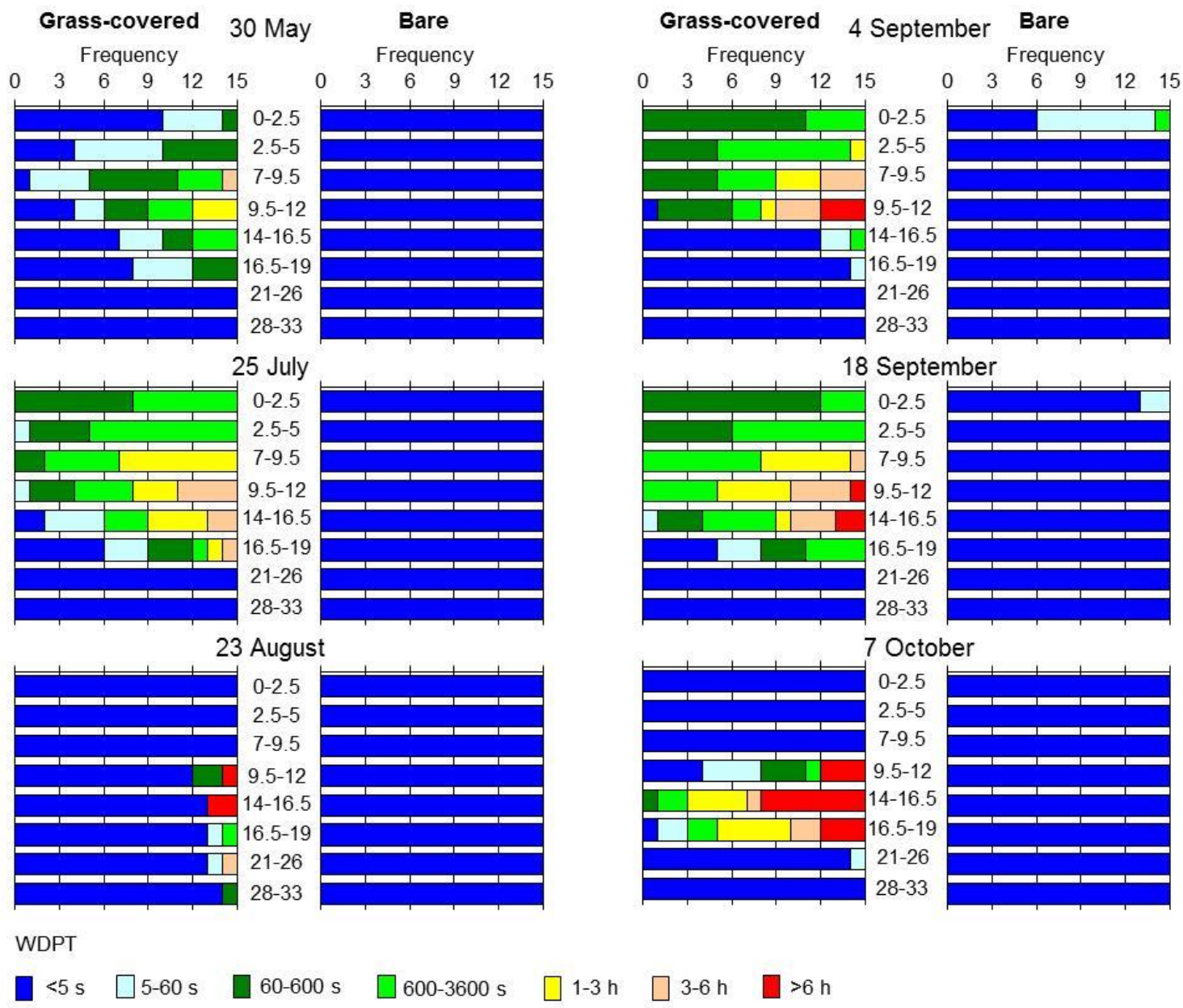

Fig. 5. Frequency of the persistence of actual water repellency (WDPT class) of field-moist soil samples taken at eight depths in the grasscovered and bare plot of site 2 between 30 May and 7 October $(n=15)$.

depth in the grass-covered plot (Fig. 4). The disappearance was caused by the $41 \mathrm{~mm}$ precipitation surplus since the previous sampling (Fig. 6). Noteworthy is the extreme persistence of the major part of the remaining water repellent samples, which conclusively is related to the presence of dry soil bodies next to preferential flow paths in the soil profile.

A dry period, with a precipitation deficit of $30 \mathrm{~mm}$ occurred from 7 August to 12 September (Fig. 6). The existence of actual water repellency in the grass-covered plot extended, as a result of this relatively dry period. All samples taken between 2.5 and $12 \mathrm{~cm}$ were water repellent and most of them even extremely (Fig. 4). The soil profile of the bare plot continued to be entirely wettable, notwithstanding the prior relatively dry period.

From 13 to 27 September a precipitation surplus of $10 \mathrm{~mm}$ occurred (Fig. 6). We assume that the extent of water repellency to $26 \mathrm{~cm}$ depth in the grass-covered plot took place between 12 and 21 September. On the other hand, the disappearance and decrease of repellency at depths of $0-5 \mathrm{~cm}$, was a consequence of the rain events prior to the sampling.

After periods with a cumulative precipitation deficit wettable and slightly to extremely water repellent soil samples were also found between 0 and $19 \mathrm{~cm}$ depth in the grass-covered plot of site 2 on 30 May, 25 July, and 4 and 18 September (Fig. 5). In contrast near all 120 samples of the bare plot were wettable on these dates.
The major portion of the soil profile of the grass-covered plot was wettable on 23 August, as a consequence of a cumulative precipitation surplus since the previous sampling (Fig. 6). A precipitation surplus previous to the sampling on 7 October resulted in a completely wettable soil profile to a depth of 9.5 $\mathrm{cm}$. On both days the soil profiles of the bare plot were entirely wettable.

\section{Range of critical soil water contents at several depths}

The soil water contents of the transition zone of the grasscovered plots are given in Table 3. The transition zone for $0-2.5 \mathrm{~cm}$ depth ranged from 16.9 to 23.5 vol.\%. This means that all collected soil samples with a soil water content below 16.9 vol.\% exhibited water repellency and that those above 23.5 vol.\% were wettable. The range of the transition zone decreases with depth. For example at depths of $21-26 \mathrm{~cm}$ the soil was repellent below a water content of 2.5 and wettable above 2.7 vol.\%. No transition zone could be distinguished for depths of $28-33 \mathrm{~cm}$, due to the existence of hardly any water repellent sample during the study period.

For the bare soil the transition zone could only be assessed at 0-2.5 cm, which ranged between 12.0 and 15.7 vol.\%. The surface layer of the bare plots appears to be wettable and to become water repellent at lower soil water contents when compared with the grass-covered plots. 


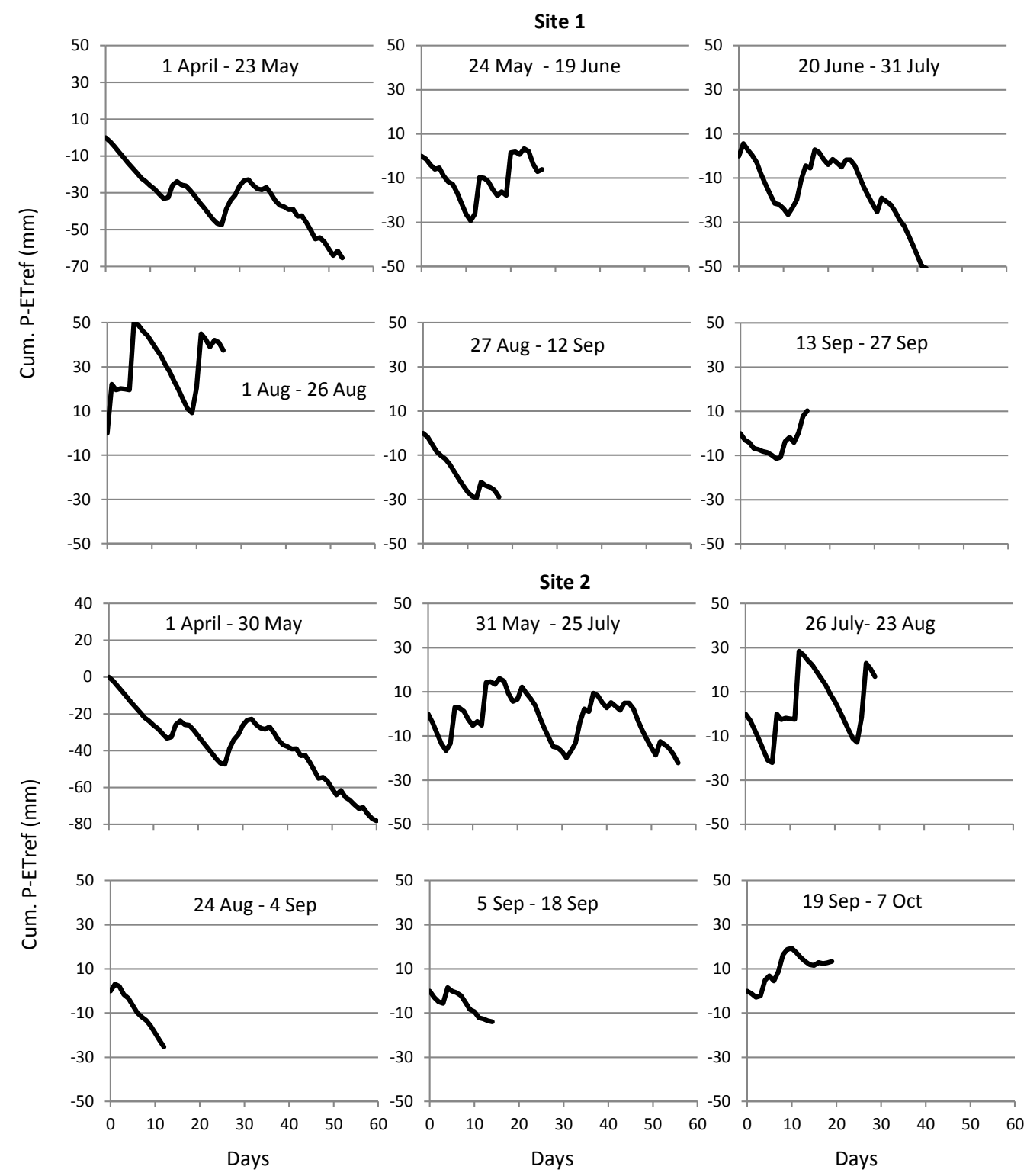

Fig. 6. Cumulative deficit and surplus of precipitation for grass before and between the sampling dates of both sites.

Table 3. Range of volumetric soil water contents in the transition zone at different depths in the grass-covered plots $(n=180)$.

\begin{tabular}{cccc}
\hline $\begin{array}{c}\text { Depth } \\
(\mathrm{cm})\end{array}$ & $\begin{array}{c}\text { Transition zone } \\
(\text { vol.\%) }\end{array}$ & $\begin{array}{c}\text { Depth } \\
(\mathrm{cm})\end{array}$ & $\begin{array}{c}\text { Transition zone } \\
\text { (vol.\%) }\end{array}$ \\
\hline $0-2.5$ & $16.9-23.5$ & $14-16.5$ & $2.9-5.5$ \\
$2.5-5$ & $7.5-17.0$ & $16.5-19$ & $2.8-3.3$ \\
$7-9.5$ & $5.1-11.1$ & $21-26$ & $2.5-2.7$ \\
$9.5-12$ & $2.8-6.1$ & & \\
\hline
\end{tabular}

\section{Spatial and temporal distribution of soil water content and persistence of water repellency}

The contour plot of 26 August with the spatial soil moisture distribution in the transect of the grass-covered plot of site 1 clearly shows patches of dry soil with preferential flow paths between them (Fig. 7). The distribution layer near the surface received the precipitation and fed the preferential flow paths below it by lateral flow. The contour plot with the distribution of actual water repellency on this date (also Fig. 7), indicates that the preferential flow paths were wettable, alongside which rapid transport of water and solutes could take place. Underneath the dry pockets, the soil was wettable too and transport was not restricted anymore to a part of the profile only. That's why, from this depth onward, a restraining influence on transport velocity could be expected. The diagrams of 27 September show a thin distribution layer, which is wet and wettable, and overlies a thick, relatively dry and predominantly extremely water repellent soil layer.

The diagrams of the bare plot of site 1 show higher water contents and a more homogeneous wetting than those of the grass-covered plot, resulting in entirely wettable transects on both dates (Fig. 7).

Also the diagrams of the bare plot from 30 May and 7 October of site 2 show relatively high soil water contents, which decrease with depth (Fig. 8). Horizontally only minor differences in soil water content are present in both, entirely wettable, transects.

On 30 May a key part of the soil profile of the grass-covered plot of site 2 was relatively dry, with soil water contents ranging from 2 to 6 vol.\% (Fig. 8). An irregular distribution of wettable, slight, strong, severe, and extreme water repellency 


\section{Site 1}
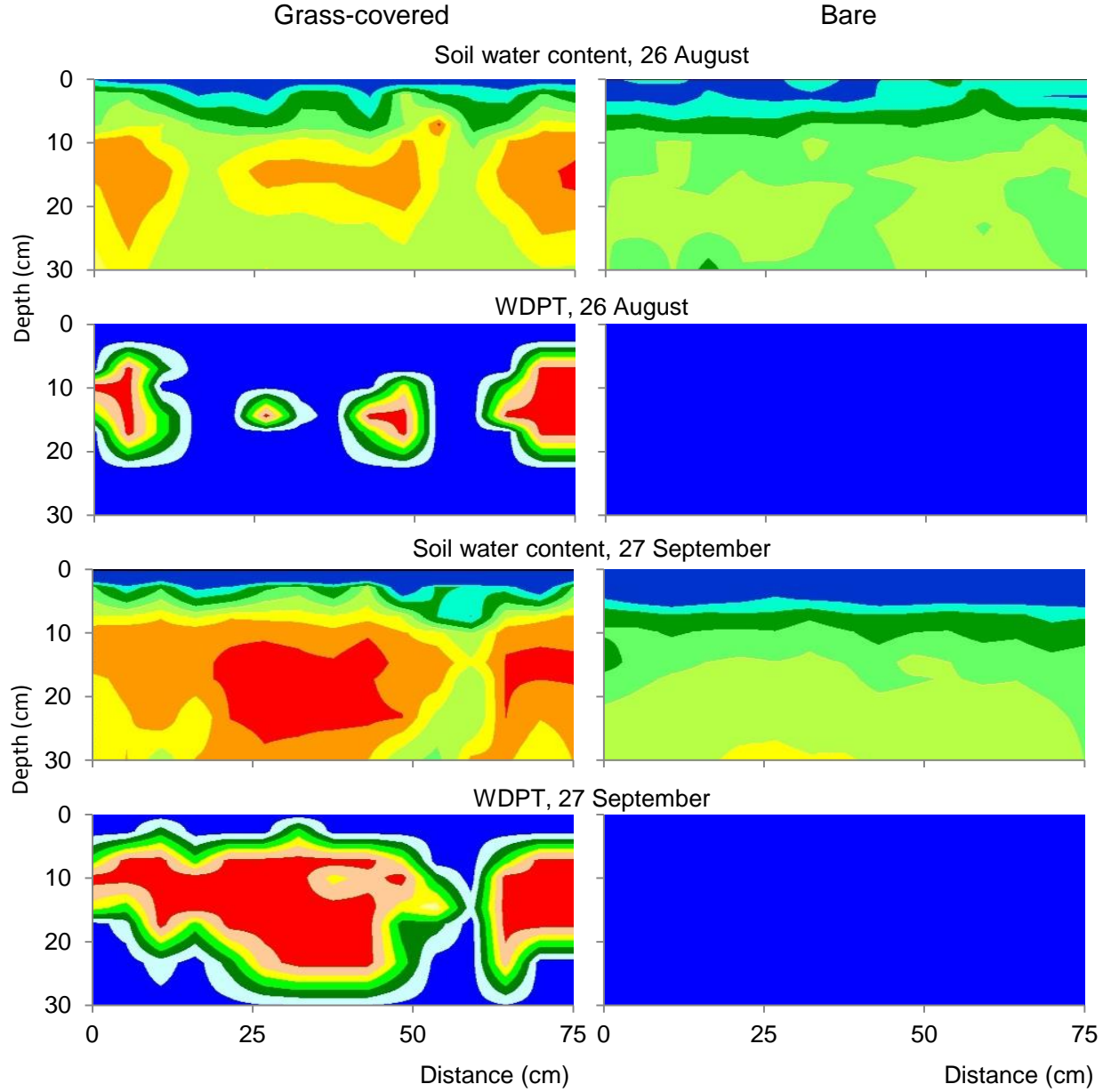

Soil water content (vol.\%)

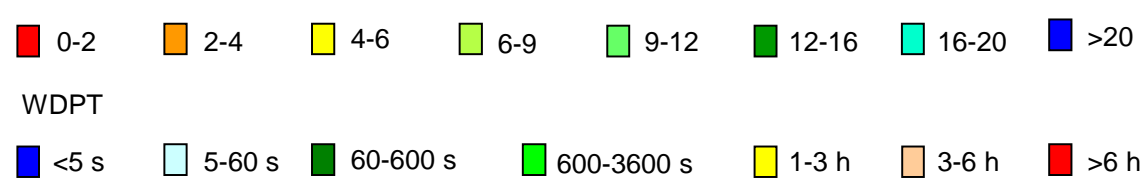

Fig. 7. Contour plots of the volumetric water content and persistence of actual water repellency in the soil profiles of the grass-covered and bare plot of site 1 on 26 August and 27 September.

was present in this transect. On 7 October the surface layer was wet with water contents exceeding $20 \mathrm{vol} . \%$, however at depths of 10 to $30 \mathrm{~cm}$ the soil water content was limited to 6 vol. $\%$, and preferential flow paths were not present. The soil between 10 and $25 \mathrm{~cm}$ depth was entirely water repellent, and an excessive part of it was even extremely water repellent.

\section{DISCUSSION}

Water repellency is a common phenomenon in course textured soils with grass cover, and besides in sandy pastures, meadows, and nature reserves (e.g. Dekker and Jungerius, 1990; Dekker et al., 2005; Lichner et al., 2011; Oostindie et al., 2013; Orfánus et al., 2016; Rodný et al., 2015). It has also been observed in sandy fairways, sand-based tees and greens of golf courses all over the world (e.g. Aamlid et al., 2009; Moore et al., 2010; Oostindie et al., 2008, 2011; Wallis et al., 1989).

The results of the grass-covered soil are consistent with the widespread assumption that water repellency is a transient phenomenon occurring more markedly in dry soils than in wet soils (Benito Rueda et al., 2015; Keizer et al., 2007; RodríguezAlleres and Benito, 2011).

The generally accepted main cause of water repellency is the presence of soil organic matter. This results in the mutual observations that the topsoil usually shows the highest repellency persistence of the soil profile (Aamlid et al., 2009; Lichner et al., 2011; Wallis et al., 1989). However, the extent of the water repellent layer in soils varies from limited to the surface layer only to existence at greater depth up to $55 \mathrm{~cm}$ below soil surface (Dekker et al., 2000; Täumer et al., 2005).

In the present study extreme water repellency with WDPT values exceeding $6 \mathrm{~h}$ were often assessed in the grass-covered plots at depths of 7-26 cm, even in autumn. It is noteworthy that extreme water repellency was often found in the subsoil with relatively low organic matter contents. It may be that the development of water repellency in the surface layer is related to organic matter particles, while deeper in the profile the cause may be hydrophobic coatings on the sand grains are the main 
Site 2
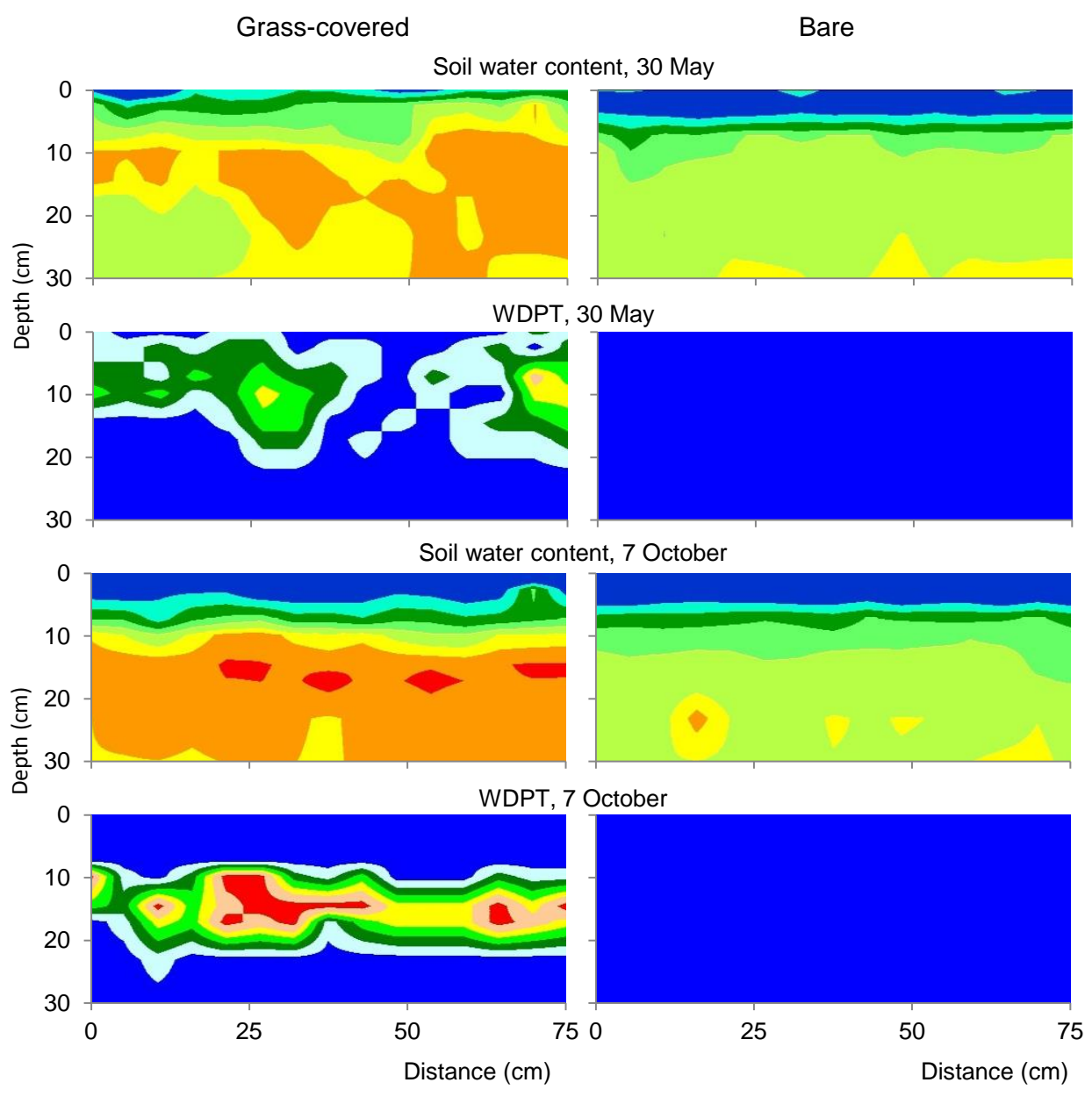

Soil water content (vol.\%)

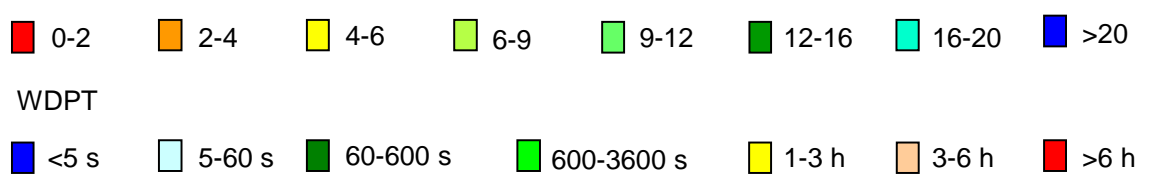

Fig. 8. Contour plots of the volumetric water content and persistence of actual water repellency in the soil profiles of the grass-covered and bare plot of site 2 on 30 May and 7 October.

source of it. However more work is required to test this theory, because also non-degraded organic compounds could increase soil water repellency, as established by Sándor et al. (2015). It is interesting that the greatest water repellency values are not necessarily observed in the surface layer, but also in deeper layers. This is relevant for water transport features such as lateral distribution at the soil surface and fingering flow bypassing large water repellent zones in the soil matrix. Furthermore, a dried out layer at the top of the soil may largely prevent or even completely block the evaporation from the soil surface.

A major part of the soil profile in the grass-covered plots exhibited extreme water repellency to a depth of 19 to $26 \mathrm{~cm}$ on all sampling dates, while the soil profile of the bare plots was completely wettable on eight of the twelve sampling dates. Remarkable are the often huge spatial differences in persistence of actual water repellency in the grass-covered plots across a horizontal difference of $75 \mathrm{~cm}$, with wettable as well as slightly, strongly, severely, and extremely water repellent soil samples. These differences in persistence may partly be due to differences in soil water content, but may also be the result of differences in hydrophobic compounds and their concentrations as found by Mao et al. (2014, 2015). Gordon and Hallett (2014) describe even the spatial variability of the severity of soil water repellency at the millimetre scale by means of the contact angle.

Substantially higher soil water contents were measured in the bare versus the grass-covered plots. These alterations are caused by differences between evaporation and transpiration rates across the plots. The evaporation is increased in bare plots because the wind speed and the temperature at the soil surface are great: the bare soils are directly exposed to sunshine and the black colour of ash increases the absorption of radiation, in particular at the surface layer. However, transpiration decreases in bare plots because the transpiring surface is substantially reduced, due to the elimination of the aerial parts of the grass plants. Water loss by transpiration comes from all soil layers in the root zone, whereas direct evaporation from the soil is restricted to the upper layer. For these reasons, during times of a precipitation deficit, water content decreases throughout the 
profile in the grass-covered plots but only at the top of the soil in the bare plots. Figure 2 clearly shows this phenomenon. With the exception of 3 sampling days (25 July, 4 and 12 September) there were no huge differences found in soil water content between the grass-covered and bare plots in the top layer $(0-2.5 \mathrm{~cm})$. But, in the bare plots the soil water contents were always higher. Further it can be seen that the soil water contents of the second layer at the bare plots were always above 15 and for half of all cases even above $20 \mathrm{vol} . \%$. At the grass-covered plots the soil water content dropped frequently below 10 vol.\%. This endorses the viewpoint above regarding the effects of transpiration and evaporation between treatments. The water storage in the upper $19 \mathrm{~cm}$ of the bare soil was at least two times greater during dry periods. Striking are the small temporal changes in mean soil water content at depths between 9.5 and $33 \mathrm{~cm}$ in both bare plots from spring to autumn during the period studied.

\section{CONCLUSIONS}

Considerable higher soil water contents were found in the bare versus the grass-covered plots. The water storage in the upper $19 \mathrm{~cm}$ of the bare soil was at least two times greater than in the grass-covered soil during dry periods.

A major part of the soil profile in both grass-covered plots exhibited severe to extreme water repellency to a depth of 19 $\mathrm{cm}$ on all sampling dates, while the soil profile of the bare plots was completely wettable on eight of the twelve sampling dates. The persistence of actual soil water repellency at the six depths between 0 and $19 \mathrm{~cm}$ in both grass-covered plots was significantly higher $(\mathrm{P}<0.05)$ than in the bare plots on 23 May, 30 May, 19 June, 25 July, 12 September, and 18 September. On 31 July, 26 August, 27 September and 7 October the persistence of actual water repellency in the grass-covered plots was significant higher $(\mathrm{P}<0.05)$ than in the bare plots at greater depths, but insignificant in the upper sampled layers one, two, two, and three on the respective dates.

Acknowledgement. This work was supported by the European Union Seventh Framework Programme Theme (EUV.2011.2.1.4-2, Grant Agreement No. 283068.) Catastrophic shifts in dry lands: how can we prevent ecosystem degradation - Cascade. However, this work does not necessarily reflect the Commission's view and in no way anticipated its future policy in this area. We are grateful for the proofreading of the concept paper by Prof. Tammo Steenhuis, whose comments helped improving this manuscript in an important way. Dr. Jan Oude Voshaar is greatly thanked for the statistical analysis. The authors would like to thank the two anonymous reviewers for their suggestions and comments that helped to improve the manuscript.

\section{REFERENCES}

Aamlid, T.S., Espevig, T. Kvalbein, A., 2009. The potential of a surfactant to restore turfgrass quality on a severely waterrepellent golf green. Biologia, 64, 3, 620-623. DOI: 10.2478/s11756-009-0071-1.

Bauters, T.W.J., Steenhuis, T.S., DiCarlo, D.A., Nieber, J.L., Dekker, L.W., Ritsema, C.J., Parlange, J-Y., Haverkamp, R., 2000. Physics of water repellent soils. Journal of Hydrology, 231-232, 233-243. DOI: 10.1016/S00221694(00)00197-9.

Benito Rueda, E., Rodríguez-Alleres, M., Varela Teijeiro, E., 2015. Environmental factors governing soil water repellency dynamics in a Pinus pinaster plantation in NW Spain. Land Degradation \& Development, 27, 3, 719-728. DOI: 10.1002/ldr.2370.

Bisdom, E.B.A., Dekker, L.W., Schoute, J.F.T., 1993. Water repellency of sieve fractions from sandy soils and relationships with organic material and soil structure. Geoderma, 56, 105-118. DOI:10.1016/0016-7061(93)90103-R.

Dekker, L.W., Jungerius, P.D., 1990. Water repellency in the dunes with special reference to the Netherlands. Catena Supplement, 18, 173-183.

Dekker, L.W., Ritsema, C.J., 1994. How water moves in a water repellent sandy soil. 1. Potential and actual water repellency. Water Resources. Research, 30, 9, 2507-2517. DOI:10.1029/94WR00749.

Dekker, L.W., Ritsema, C.J., Wendroth, O., Jarvis, N., Oostindie, K., Pohl, W., Larson, M., Gaudet, J.P., 1999. Moisture distributions and wetting rates of soils at experimental fields in The Netherlands, France, Sweden and Germany. Journal of Hydrology, 215, 4-22. DOI: 10.1016/S00221694(98)00258-3.

Dekker, L.W., Ritsema, C.J., Oostindie, K., 2000. Extent and significance of water repellency in dunes along the Dutch coast. Journal of Hydrology, 231-232, 112-125. DOI: 10.1016/S0022-1694(00)00188-8.

Dekker, L.W., Doerr, S.H., Oostindie, K., Ziogas, A.K., Ritsema, C.J., 2001. Water repellency and critical soil water content in a dune sand. Soil Science Society of America Journal, 65, 1667-1674. DOI: 10.2136/sssaj2001.1667.

Dekker, L.W., Oostindie, K., Ritsema, C.J., 2005. Exponential increase of publications related to soil water repellency. Australian Journal of Soil Research, 43, 403-441. DOI: 10.1071/SR05007.

Dekker, L.W., Ritsema, C.J., Oostindie, K., Moore, D., Wesseling, J.G., 2009. Methods for determining soil water repellency on field-moist samples. Water Resources Research, 45, W00D33. DOI:10.1029/2008WR007070.

Doerr, S.H., Dekker, L.W., Ritsema, C.J., Shakesby, R.A., Bryant R., 2002. Water repellency of soils. The influence of ambient relative humidity. Soil Science Society of. America Journal, 66, 401-405. DOI: 10.2136/sssaj2002.0401.

Gordon, D.C., Hallett, P.D., 2014. An automated microinfiltrometer to measure small-scale soil water infiltration properties. Journal of Hydrology and Hydromechanics, 62, 3, 248-252. DOI: 10.2478/johh-2014-0023.

Greiffenhagen, A., Wessolek, G., Facklam, M., Renger, M., Stoffregen, H., 2006. Hydraulic functions and water repellency of forest floor horizons on sandy soils. Geoderma, 132, 182-195. DOI:10.1016/j.geoderma.2005.05.006.

Heijs, A.W.J., Ritsema, C.J., Dekker, L.W., 1996. Threedimensional visualization of preferential flow patterns in two soils. Geoderma, 70, 101-116. DOI: 10.1016/00167061(95)00076-3.

Jaramillo, D.F., Dekker, L.W., Ritsema, C.J., Hendrickx, J.M.H., 2000. Occurrence of soil water repellency in arid and humid climates. Journal of Hydrology, 231-232, 105111. DOI: 10.1016/S0022-1694(00)00187-6.

Keizer, J.J., Doerr, S.H., Malvar, M.C., Ferreira, A.J.D., Peirera, V.M.F.G., 2007. Temporal and spatial variations in topsoil water repellency throughout a crop-rotation cycle on sandy soil in north-central Portugal. Hydrological Processes, 21, 2317-2324. DOI: 10.1002/hyp.6756.

Letey, J., Carrillo, M.L.K., Pang, X.P., 2000. Approaches to characterize the degree of water repellency. Journal of Hydrology, 231-232, 61-65. DOI: 10.1016/S00221694(00)00183-9. 
Lichner, L., Hallett, P.D., Orfánus, T., Czachor, H., Rajkai, K., Sir, M., Tesar, M., 2010. Vegetation impact on the hydrology of an Aeolian sandy soil in a continental climate. Ecohydrology, 3, 413-420. DOI: 10.1002/eco.153.

Lichner, L., Eldridge, D.J., Schacht, K., Zhukova, N., Holko, L., Sír, M., Pecho, J., 2011. Grass cover influences hydrophysical parameters and heterogeneity of water flow in a sandy soil. Pedosphere 21, 6, 719-729.

MacCullagh, P., Nelder, J.A., 1989. Generalized Linear Models. 2nd ed. Chapman and Hall, London.

Mao, J., Nierop, K.G.J., Sinninghe Damsté, J.S., Dekker, S.C., 2014. Roots induce stronger soil water repellency than leaf waxes. Geoderma, 232-234, 328-340. DOI: 10.1016/j.geoderma.2014.05.024.

Mao, J., Nierop, K.G.J., Rietkerk, M., Dekker, S.C., 2015. Predicting soil water repellency using hydrophobic organic compounds and their vegetation origin. Soil, 1, 411-425.

Mataix-Solera, J,. Arcenegui, V., Guerrero, C., Mayoral, A.M., Morales, J., Conzález, J., García-Orenes, F., Gómez, I., 2007. Water repellency under different plant species in a calcareous forest soil in a semiarid Mediterranean environment. Hydrological Processes, 21, 2300-2309. DOI: 10.1002/hyp.6750.

Moore, D., Kostka, S.J., Boerth, T.J., Franklin, M., Ritsema, C.J., Dekker, L.W., Oostindie, K., Stoof, C., Wesseling, J., 2010. The effect of soil surfactants on soil hydrological behavior, the plant growth environment, irrigation efficiency and water conservation. Journal of Hydrology and Hydromechanics, 58, 3, 142-148. DOI: 10.2478/v10098-0100013-1.

Morley, C.P., Mainwaring, K.A., Doerr, S.H., Douglas, P., Llewellyn, C.T., Dekker, L.W., 2005. Organic compounds at different depths in a sandy soil and their role in water repellency. Australian Journal of Soil Research, 43, 239-249. DOI: $10.1071 /$ SR04094.

Oostindie, K., Dekker, L.W., Wesseling, J.G., Ritsema, C.J., 2008. Soil surfactant stops water repellency and preferential flow paths. Soil Use and Management, 24, 409-415. DOI: 10.1111/j.1475-2743.2008.00185.x.

Oostindie, K., Dekker, L.W., Wesseling, J.G., Ritsema, C.J., 2011. Improvement of water movement in an undulating sandy soil prone to water repellency. Vadose Zone Journal, 10, 262-269. DOI: 10.2136/vzj2010.0051.

Oostindie, K., Dekker, L.W., Wesseling, J.G., Ritsema, C.J., Geissen, V., 2013. Development of actual water repellency in a grass-covered dune sand during a dehydration experiment. Geoderma, 204-205, 23-30. DOI: 10.1016/j.geoderma.2013. 04.006.
Orfánus, T., Stojkovová, D., Rajkai, K., Czachor, H., Sándor, R., 2016. Spatial patterns of wetting characteristics in grassland sandy soil. Journal of Hydrology and Hydromechanics, 62, 2, 167-175. DOI: 10.1515/johh-2016-0010.

Ritsema, C.J., Dekker, L.W., 1995. Distribution flow: A general process in the top layer of water repellent soils. Water Resources Research, 31, 1187-1200. DOI: 10.1029/94WR02979.

Ritsema, C.J., Dekker, L.W., Heijs, A.W.J., 1997. Threedimensional fingered flow patterns in a water repellent sandy field soil. Soil Science, 162, 79-90. DOI: 10.1097/00010694-199702000-00001.

Rodný, M., Lichner, L., Schacht, K., Holko, L., 2015. Depthdependent heterogeneity of water flow in sandy soil under grass. Biologia, 70, 11, 1462-1467. DOI: 10.1515/biolog2015-0167.

Rodríguez-Alleres, M., Benito, E., 2011. Spatial and temporal variability of surface water repellency in sandy loam soils of NW Spain under Pinus pinaster and Eucalyptus globulus plantations. Hydrological Processes, 25, 3649-3658. DOI: 10.1002/hyp.8091.

Sándor, R., Lichner, L., Filep, T., Balog, K., Lehoczky, É., Fodor, N., 2015. Spatial variability of hydrophysical properties of fallow sandy soils. Biologia, 70, 11, 1468-1473. DOI: 10.1515/biolog-2015-0182.

Soil Survey Staff, 2006. Keys to Soil Taxonomy. 10th ed. NRCS, Washington, DC.

Täumer, K., Stoffregen, H., Wessolek, G., 2005. Determination of repellency distribution using soil organic matter and water content. Geoderma, 125, 107-115. DOI: 10.1016/j.geoderma.2004.07.004.

Wallis, M.G., Horne, D.J., McAuliffe, K.W., 1989. A survey of dry patch and its management in New Zealand golf greens. 2. Soil core results and irrigation interaction. New Zealand Turf Management Journal, 3, 4, 15-17.

Wessolek, G., Schwärzel, K., Greiffenhagen, A., Stoffregen, H., 2008. Percolation characteristics of a water-repellent sandy forest soil. European Journal of Soil Science, 59, 1423. DOI: 10.1111/j.1365-2389.2007.00980.x.

Wessolek, G., Stoffregen, H., Täumer, K., 2009. Persistency of flow patterns in a water repellent sandy soil - Conclusions of TDR readings and a time-delayed double tracer experiment. Journal of Hydrology, 375, 524-535. DOI: 10.1016/j.jhydrol.2009.07.003.

Received 13 July 2016 Accepted 30 September 2016 